\title{
DNA damage and cellular abnormalities in tuberculosis, lung cancer and chronic obstructive pulmonary disease
}

Andréa Lúcia Gonçalves da Silva ${ }^{1 *}$, Maribel Josimara Bresciani ${ }^{2}$, Thaís Evelyn Karnopp ${ }^{2}$, Augusto Ferreira Weber ${ }^{2}$, Joel Henrique Ellwanger ${ }^{2,3}$, João Antonio Pêgas Henriques ${ }^{3}$, Andréia Rosane de Moura Valim ${ }^{2,4}$

and Lia Gonçalves Possuelo ${ }^{2,4}$

\begin{abstract}
Background: Tuberculosis (TB), Lung Cancer (LC) and Chronic Obstructive Pulmonary Diseases (COPD) affect millions of individuals worldwide. Monitoring of DNA damage in pathological situations has been investigated because it can add a new dimension to clinical expression and may represent a potential target for therapeutic intervention. The aim of this study was to evaluate DNA damage and the frequency of cellular abnormalities in TB, LC and COPD patients by comparing them to healthy subjects.

Methods: The detection of DNA damage by a buccal micronucleus cytome assay was investigated in patients with $\operatorname{COPD}(n=28), \mathrm{LC}(n=18)$ and TB $(n=22)$ and compared to control individuals $(n=17)$.

Results: The COPD group had a higher frequency of apoptotic cells compared to TB and LC group. The TB group showed a higher frequency of DNA damage, defect in cytokinesis, apoptotic and necrotic cells. Patients with LC had low frequency of chromosomal aberrations than TB and COPD patients.

Conclusion: COPD patients showed cellular abnormalities that corresponded to cell death by apoptosis and necrosis, while patients with TB presented defects in cytokinesis and dysfunctions in DNA repair that resulted in the formation of micronucleus (MN) besides apoptotic and necrotic cells. Patients with COPD, TB and LC had a low frequency of permanent DNA damage.
\end{abstract}

Keywords: Apoptosis, Micronucleus, Necrosis, Pulmonary diseases

\section{Background}

The prevalence of chronic obstructive pulmonary disease (COPD) in Brazil is estimated at 7.3 million individuals [1]. The most recent global estimate indicated an incidence of 1.82 million new cases of lung cancer (LC) in 2012 [2]. In 2013, there were approximately 9.0 million people with tuberculosis (TB) worldwide [3].

Constant oxidative stress in the lung cells of the elderly serves as a source of free radicals that damage the DNA of pulmonary and circulating cells [4-6], thereby contributing to the pathogenesis of lung

\footnotetext{
* Correspondence: andreag@unisc.br

'Department of Health and Physical Education, University of Santa Cruz do Sul - UNISC, Avenida Independência, 2293, Bairro Universitário, Santa Cruz do Sul, RS CEP 96815-900, Brazil

Full list of author information is available at the end of the article
}

diseases. However, little is known about the levels of DNA damage in the three diseases evaluated in this study.

The synergistic effects of breathable particles lead to oxidative stress. These particles have a high carcinogenic potential and can lead to the increased production of pulmonary inflammatory mediators that cause oxidative damage to all major cellular components (i.e., membrane lipids, proteins, and DNA) [4-6]. Genomic instability is characterized by an increased frequency of changes in the genetic material of the cells. Loss of genomic stability is one of the most important aspects of mutagenesis and the genetic changes associated with carcinogenesis. One way to detect genomic instability is to quantify the frequency of chromosomal alterations induced by mutagens. It is currently accepted that DNA damage directly

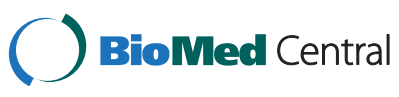

(c) 2015 da Silva et al. Open Access This article is distributed under the terms of the Creative Commons Attribution 4.0 International License (http://creativecommons.org/licenses/by/4.0/), which permits unrestricted use, distribution, and reproduction in any medium, provided you give appropriate credit to the original author(s) and the source, provide a link to the Creative Commons license, and indicate if changes were made. The Creative Commons Public Domain Dedication waiver (http://creativecommons.org/publicdomain/zero/1.0/) applies to the data made available in this article, unless otherwise stated. 
or indirectly caused by mutagenic and carcinogenic agents is primarily responsible for chromosomal abnormalities. Therefore, DNA damage deserves special attention from health centers and the scientific community, and its monitoring is useful for routine testing to prevent different pathologies [7].

The micronucleus $(\mathrm{MN})$ in dividing cells forms as a result of chromosome breakage due to unrepaired or misrepaired DNA lesions. Chromosomal malsegregation due to mitotic malfunction can also result in the formation of the MN [8]. These events may be induced by oxidative stress, exposure to clastogens, or genetic defects that affect the cell cycle and/or DNA repair genes. Deficiencies in the nutrients that function as required cofactors for DNA metabolism can also play a role in the process of MN formation [8-10]. All these molecular events are associated with the formation of the MN and they are observed in patients with lung diseases $[4,8,11]$. The MN assay in exfoliated cells can be used as an internal dosimeter of DNA damage in specific tissues. The oral epithelium is in constant contact with genotoxic environmental agents; therefore, it is an important target site of inhaled or ingested toxic substances [12]. Damage to the oral epithelium indirectly indicates damage to lung cells, because the damage-inducing agents that enter the body through the oral epithelium will also reach the lungs.

The risk of mortality in patients with COPD, LC or TB is directly related to the exacerbation and progression of each disease. Oxidants are formed due to an exacerbated inflammatory process, especially in individuals with an impaired immune response $[6,13,14]$. Genetic and environmental factors, DNA integrity and lifestyle respectively, together with clinical parameters, may contribute to personalize clinical process and therapeutic strategy [15]. Therefore, the aim of this study was to evaluate permanent DNA damage in patients with COPD, LC and TB by comparing them to healthy subjects, and to identify the frequency of cellular abnormalities in these individuals.

\section{Methods}

A case-control study was performed with 28 patients with COPD (age 64.21 \pm 8.20 ), 18 with LC (age 65.06 \pm 6.64 ), and 22 with TB (age $36.09 \pm 16.25$ ) at the beginning of medical treatment. The control group was composed of healthy subjects with preserved lung functions $(n=17$, age $62.82 \pm 4.78$ ). Data collection and patient sampling were performed in the following locations: COPD - Cardio Respiratory Rehabilitation Program at Santa Cruz Hospital (SCH, Rio Grande do Sul, Brazil); LC - Integrated Oncology Center at Ana Nery Hospital (Rio Grande do Sul, Brazil); TB - TB Clinic at SCH.

Individuals with preserved lung functions that were exposed to the same living conditions and were similar in terms of gender, age and body mass index
(BMI) were included in the control group. These individuals were recruited from the Family Health Units located at Rio Pardo and Taquari Valleys (Rio Grande do Sul, Brazil). The protocol of this study was approved by the Ethics Committee of the University of Santa Cruz do Sul - UNISC (protocol number: 374.298). All participants answered a personal health questionnaire and signed an informed consent form.

\section{Buccal micronucleus cytome assay (BMCyt)}

We adapted the BMCyt assay from the method described by Thomas et al. [16]. Buccal cell samples were collected and processed in accordance with the same authors. The cells were directly fixed in methanol (an adaptation of the original protocol). For each subject, two microtubes were prepared with methanol for left cheek and right cheek cells. The cells were collected by rotating a cytobrush in a spiral motion 20 times against the inner surface of the cheek wall. The head of the cytobrush was placed into its respective micro tube containing $1000 \mu \mathrm{L}$ of methanol $[17,18]$. Then, the samples were transported to the laboratory and kept under refrigeration $\left(5^{\circ} \mathrm{C}\right)$ prior to performing the micronucleus test.

The cells were centrifuged and washed with methanol after the supernatant has been removed to concentrate a larger number of cells. Approximately $200 \mu \mathrm{L}$ of the cell suspension was spread over a microscope slide and allowed to dry. Then, the slides were placed in a staining jar containing $50 \%$ ethanol for $1 \mathrm{~min}$ and immediately transferred to a staining jar containing $20 \%$ ethanol for 1 additional minute. After washing the slides with deionized water for $2 \mathrm{~min}$, hydrochloric acid $5 \mathrm{M}$ was added for $30 \mathrm{~min}$ to allow cell hydrolysis.

After cell hydrolysis, the slides were washed in tap water for $5 \mathrm{~min}$ and then with distilled water for $1 \mathrm{~min}$. Subsequently, the slides were maintained for $1 \mathrm{~h}$ and 20 min in Schiff's reagent for staining and then washed with distilled water. After staining, the cells were counterstained with Fast Green for 20 seconds and then washed with distilled water for $2 \mathrm{~min}$. The slides/cells were dried at room temperature and stored for microscopic analysis. Slide analysis was performed single-blind using a conventional optical microscope at a 400X magnification. A total of 2,000 cells per slide were analyzed, for a total count of 4,000 cells per sample.

\section{Cell classification}

The BMCyt can be used as an indicator of DNA damage (MN and/or nuclear buds - BUDS), cytokinesis defects (binucleated cells - BC), proliferation potential (basal cell frequency), apoptotic cell death (condensed chromatin CC, karyorrhectic cells - KR, pyknotic cells - PY) and 
necrosis (karyolitic cells - KL) [16]. All these cell characteristics were analyzed in the samples.

\section{Statistical analysis}

Statistical analysis was performed by descriptive methods (i.e., mean, standard deviation, median, frequency and quartiles); multiple comparisons were accomplished using the analysis of variance (ANOVA) with the post-hoc Tukey test. The associations between the studied parameters were evaluated using the Spearman correlation test in the Statistical Package for the Social Sciences (SPSS) software version 20.0. Differences were considered to be significant with $\mathrm{p}<0.05$.

\section{Results}

The general characteristics of patients with respiratory disease and individuals from the control group are provided in Table 1. There was a predominance of male subjects, caucasians and adults in both case and control groups. It is noteworthy that all subjects were in advanced adulthood ( $>60$ years), with the exception of patients with TB. The smoking status was also prevalent among individuals from the case groups, with a high consumption of cigarettes per year.

The COPD group had a higher frequency of apoptotic cells compared to $\mathrm{TB}$ and LC group. The TB group showed a higher frequency of DNA damage, defect in cytokinesis and necrotic cells (Table 2).

\section{Discussion}

In our study, COPD patients were characterized by a higher frequency of cells with characteristics of programmed cell death and necrosis. In the COPD pathology, the pattern of apoptosis is associated with an increased immune response, especially during exacerbation of the disease [19]. The regulation of apoptosis can be influenced by the inflammatory process that is elevated during exacerbated COPD, thereby contributing to a significant increase in the frequency of apoptosis of circulating lymphocytes compared with stable COPD patients [19]. Cell death by apoptosis is genetically programmed and mediated by caspase activation. In contrast, necrosis can normally be considered as a pathological death caused by physical stress or exposure to highly toxic stimuli [20]. The role of necrosis in the pathogenesis of COPD is poorly understood, but the existence of a form of genetically programmed and regulated necrosis called necroptosis is being investigated [21].

In contrast, patients with $\mathrm{TB}$ in this study showed a cellular frequency consistent with problems in cytokinesis, DNA repair and DNA damage. The damage of cells by oxidative stress can lead to $\mathrm{MN}$ formation as a result of non-repaired or misrepaired DNA damage or chromosome malsegregation, but these damaged cells may also be susceptible to elimination by apoptosis when the level of damage is very high [8]. A study showed a significant increase in cytogenetic markers $(\mathrm{MN})$ after six months of classical antituberculosis therapy compared to control and untreated subjects [11]. The apoptosis in the cells of patients with tuberculosis is associated with a protective response against infection with Mycobacterium tuberculosis, while a necrotic response favors infection by the pathogen [22, 23]. Consistently, M. tuberculosis inhibits signaling associated with apoptosis of the host cell, but promotes the induction of programmed necrosis. Dysregulation of the cell death pathways involved in necrosis can promote the release of viable bacilli, thereby leading to the progression of tuberculosis [24]. According to what described above we also observed higher frequency of apoptotic and necrotic cells in TB group. Importantly, the mean age of the TB group was considerably lower than that observed in the other groups (including the control group). This data is very interesting and should be taken into consideration when interpreting the results because it highlights the importance of the disease in the induction of DNA damage even in younger populations.

Table 1 Characteristics of research subjects

\begin{tabular}{|c|c|c|c|c|}
\hline & COPD & LC & TB & Control \\
\hline & $n=28$ & $n=18$ & $n=22$ & $n=17$ \\
\hline Sex (male) & 14 & 13 & 16 & 9 \\
\hline Ethnicity (Caucasian) & 23 & 14 & 10 & 17 \\
\hline Age (years) ${ }^{a}$ & $64.21 \pm 8.20$ & $65.06 \pm 6.64$ & $36.09 \pm 16.25$ & $62.82 \pm 4.78$ \\
\hline$B M l^{\mathrm{a}}$ & $24.47 \pm 4.35$ & $24.44 \pm 4.13$ & $23.67 \pm 3.74$ & $26.40 \pm 3.90$ \\
\hline Smoking status Never/Ex/Smoker & $1 / 24 / 3$ & $0 / 14 / 4$ & $9 / 4 / 9$ & $9 / 8 / 0$ \\
\hline Cigarretes-year ${ }^{\mathrm{b}, \mathrm{c}}$ & $7300(730-25550)$ & 7300 (1460-21900) & $6387(5475-14600)$ & $7200(1800-10800)$ \\
\hline
\end{tabular}

n sample size, COPD Chronic Obstructive Pulmonary Disease, LC Lung Cancer, TB Tuberculosis, BMI Body Mass Index. ${ }^{\mathrm{a} E x p r e s s e d}$ as mean \pm SD; ${ }^{\mathrm{b}} \mathrm{Cigarettes}$ smoked per year for smokers and ex-smokers; ${ }^{C}$ Expressed as median (min.-max.) 
Table 2 Micronuclei frequencies and cellular abnormalities in COPD, TB, LC patients and control subjects

\begin{tabular}{lllll}
\hline$\%$ & COPD & LC & TB & Control \\
& $n=28$ & $n=18$ & $n=22$ & $n=17$ \\
\hline Normal cells & $0.15(0.00-0.30)^{\mathrm{a}, \mathrm{c}}$ & $0.15(0.05-0.35)^{\mathrm{a}}$ & $0.65(0.40-0.90)^{\mathrm{d}}$ & $0.35(0.10-3.00)$ \\
MN (basal cells) & $0.00(0.00-0.05)$ & $0.00(0.00-0.05)$ & $0.00(0.00-0.10)$ & $0.00(0.00-0.05)$ \\
MN (differentiated cells) & $0.20(0.00-0.35)^{\mathrm{a}, \mathrm{c}}$ & $0.15(0.05-0.30)^{\mathrm{a}}$ & $0.50(0.30-0.70)^{\mathrm{a}, \mathrm{d}}$ & $0.30(0.50-3.00)$ \\
Nuclear bud & $0.10(0.00-0.25)^{\mathrm{a}, \mathrm{c}}$ & $0.10(0.05-0.30)^{\mathrm{a}}$ & $0.25(0.10-0.50)^{\mathrm{d}}$ & $0.20(0.00-1.20)$ \\
Binucleated cells & $0.10(0.05-0.20)^{\mathrm{a}, \mathrm{c}}$ & $0.15(0.05-0.30)^{\mathrm{a}}$ & $0.30(0.10-0.60)^{\mathrm{a}}$ & $0.65(0.15-1.55)$ \\
Condensed chromatin & $0.95(0.40-2.25)^{\mathrm{a}, \mathrm{c}}$ & $0.97(0.40-1.90)^{\mathrm{a}}$ & $2.20(0.60-6.60)^{\mathrm{a}, \mathrm{d}}$ & $0.05(0.00-0.60)$ \\
Karyorrhectic cells & $2.05(0.75-3.40)^{\mathrm{a}, \mathrm{b}}$ & $1.12(0.35-1.95)$ & $1.65(0.80-4.50)^{\mathrm{a}}$ & $0.25(0.00-5.00)$ \\
Pyknotic cells & $3.00(1.50-3.90)^{\mathrm{a}, \mathrm{b}, \mathrm{c}}$ & $1.37(0.40-3.15)^{\mathrm{a}}$ & $2.55(0.80-4.40)^{\mathrm{a}, \mathrm{d}}$ & $0.15(0.00-0.50)$ \\
Karyolitic cells & $2.10(0.60-3.10)^{\mathrm{b}}$ & $0.85(0.40-1.95)^{\mathrm{a}}$ & $2.20(0.90-3.60)^{\mathrm{d}}$ & $1.85(0.40-5.20)$
\end{tabular}

$n$ sample size, COPD Chronic Obstructive Pulmonary Disease, LC Lung Cancer, TB Tuberculosis, MN Micronucleus. Expressed as median (50 \%) and quartiles (25 \% - 75 \%); ${ }^{\mathrm{a}} p \leq 0.05$ between cases (COPD or LC or TB) and controls; ${ }^{\mathrm{b}} p \leq 0.05$ between COPD and LC; ${ }^{c} p \leq 0.05$ between COPD and TB; ${ }^{\mathrm{d}} p \leq 0.05$ between TB and LC

Studies of human populations exposed to environmental carcinogens have described a positive association between the level of chromosomal lesions and cancer risk [25-27]. LC patients also exhibited higher levels of MN in lymphocytes compared to control patients [26]. Our results differed from those described in the literature because few chromosomal aberrations were observed in LC patients, such as COPD patients. Patients with LC and COPD make use of various drugs, have chronic diseases and use tobacco [28, 29]. COPD patients also use inhaled corticosteroids, which can reduce DNA damage and minimize the formation of $\mathrm{MN}[30,31]$. Additionaly, continuous exposure to mutagenic and carcinogenic agents moderately can trigger an adaptive response that will protect against future DNA damage [32].

The control subjects in this study showed a frequency of DNA damage and defects in cytokinesis within the predicted normal range for the population $(0.5-2.5 \mathrm{MN}$ per 1,000 cells) [12]. Cells showing $\mathrm{MN}$ are rarely found in healthy individuals, but become more common in individuals exposed to radiation or other genotoxic agents. It is noteworthy that the control group was composed of individuals with advanced adult age and possible comorbidities, factors that may have contributed to the observed results. The determination of the MN frequency and other cellular abnormalities can be used to quantify permanent DNA damage and the frequency of chromosomal aberrations in patients with COPD, TB or LC. $\mathrm{MN}$ frequencies are extensively used in molecular epidemiology and cytogenetic analyses to assess the presence and the extent of chromosomal damage in human populations exposed to genotoxic agents or with a genetic profile susceptible to DNA damage [12, 18]. Monitoring of DNA damage in pathological situations has been investigated because it can add a new dimension to clinical expression and may also represent a potential target for therapeutic intervention [4-6, 8].

\section{Conclusion}

COPD patients showed cellular abnormalities that corresponded to cell death by apoptosis and necrosis, while patients with TB showed defects in cytokinesis and dysfunctions in DNA repair that resulted in the formation of $\mathrm{MN}$ besides apoptotic and necrotic cells. Understanding the mechanisms by which this process occurs is essential for the improvement of strategies for the prevention and treatment of lung diseases.

\section{Competing interests}

The authors declare that they have no competing interests.

\section{Authors' contributions}

ALGS, MJB, TEK and AFW collected the data and performed the experiments. ALGS, MJB, JHE, LGP, ARMV and JAPH prepared the draft of the manuscript. All of the authors contributed to the interpretation of the results and the revision of the manuscript. The final version of the manuscript was read and approved by all the authors.

\section{Acknowledgments}

The authors thank all of the volunteers who participated in this study.

\section{Financial support}

Departamento de Ciência e Tecnologia da Secretaria de Ciência, Tecnologia e Insumos Estratégicos do Ministério da Saúde (Decit/SCTIE/MS) through Conselho Nacional de Desenvolvimento Científico e Tecnológico (CNPq). Support from Fundação de Amparo à Pesquisa do Rio Grande do Sul (FAPERGS) and Secretaria Estadual da Saúde do Rio Grande do Sul (SES-RS) through Escola de Saúde Pública do Rio Grande do Sul, Hospital Santa Cruz, Projeto de Pesquisa Dano, Reparação e Susceptibilidade em Doenças Pulmonares and Laboratory of Genetics and Biotechnology - UNISC. All cited institutions are from Brazil.

\section{Author details}

${ }^{1}$ Department of Health and Physical Education, University of Santa Cruz do Sul - UNISC, Avenida Independência, 2293, Bairro Universitário, Santa Cruz do Sul, RS CEP 96815-900, Brazil. ²Department of Biology and Pharmacy, University of Santa Cruz do Sul - UNISC, Santa Cruz do Sul, RS, Brazil. ${ }^{3}$ Graduate Program in Cellular and Molecular Biology, Federal University of Rio Grande do Sul - UFRGS, Porto Alegre, RS, Brazil. ${ }^{4}$ Graduate Program in Health Promotion, University of Santa Cruz do Sul - UNISC, Santa Cruz do Sul, RS, Brazil.

Received: 30 September 2015 Accepted: 18 November 2015 Published online: 19 December 2015 


\section{References}

1. GOLD - Global Initiative for Chronic Obstuctive Lung Disease, "Global strategy for the diagnosis, management, and prevention of chronic obstructive pulmonary disease," National Institutes of Health and National Heart, Lung and Blood Institute, 2014

2. INCA - Instituto Nacional de Câncer José Alencar Gomes da Silva. Estimativa 2014: Incidência de câncer no Brasil. Brasil: Ministério da Saúde; 2014.

3. WHO - World Health Organization. Global tuberculosis report. Geneva: WHO; 2014.

4. Maluf SW, Mergener M, Dalcanale L, Costa CC, Pollo T, Kayser M, et al. DNA damage in peripheral blood of patients with chronic obstructive pulmonary disease (COPD). Mutat Res. 2007;626(1-2):180-4.

5. Nalbandian A, Yan BS, Pichugin A, Bronson RT, Kramnik I. Lung carcinogenesis induced by chronic tuberculosis infection: the experimental model and genetic control. Oncogene. 2009;28(17):1928-38.

6. Valavanidis A, Vlachogianni T, Fiotakis K, Loridas S. Pulmonary oxidative stress, inflammation and cancer: respirable particulate matter, fibrous dusts and ozone as major causes of lung carcinogenesis through reactive oxygen species mechanisms. Int J Environ Res Public Health. 2013;10(9):3886-907.

7. Ochi-Lohmann TH, Okazaki K, Madrufa MR, de Bragaça Pereira CA, Rabello-Gay MN. Radiosensitivity of blood lymphocytes from basocellular carcinoma patients, as detected by the micronucleus assay. Mutat Res. 1996:357(1-2):97-106.

8. Bonassi S, Znaor A, Ceppi M, Lando C, Chang WP, Holland N, et al. An increased micronucleus frequency in peripheral blood lymphocytes predicts the risk of cancer in humans. Carcinogenesis. 2007;28(3):625-31.

9. Fenech M, Holland N, Chang WP, Zeiger E, Bonassi S. The HUman MicroNucleus Project-An international collaborative study on the use of the micronucleus technique for measuring DNA damage in humans. Mutat Res. 1999:428(1-2):271-83.

10. Thomas P, Wu J, Dhillon V, Fenech M. Buccal micronucleus cytome assay. Methods Mol Biol. 2011;682:235-48.

11. Masjedi MR, Heidary A, Mohammadi F, Velayati AA, Dokouhaki P. Chromosomal aberrations and micronuclei in lymphocytes of patients before and after exposure to anti-tuberculosis drugs. Mutagenesis. 2000; 15(6):489-94.

12. Holland N, Bolognesi C, Kirsch-Volders M, Bonassi S, Zeiger E, Knasmueller S, et al. The micronucleus assay in human buccal cells as a tool for biomonitoring DNA damage: the HUMN project perspective on current status and knowledge gaps. Mutat Res. 2008;659(1-2):93-108.

13. Domej W, Oettl K, Renner W. Oxidative stress and free radicals in COPD-implications and relevance for treatment. Int J Chron Obstruct Pulmon Dis. 2014;9:1207-24.

14. Dorhoi A, Kaufmann SH. Perspectives on host adaptation in response to Mycobacterium tuberculosis: modulation of inflammation. Semin Immunol. 2014;26(6):533-42.

15. Milic M, Frustaci A, Del Bufalo A, Sánchez-Alarcón J, Valencia-Quintana R, Russo P, et al. DNA damage in non-communicable diseases: A clinical and epidemiological perspective. Mutat Res. 2015;776:118-27.

16. Thomas P, Holland N, Bolognesi C, Kirsch-Volders M, Bonassi S, Zeiger E, et al. Buccal micronucleus cytome assay. Nat Protoc. 2009:4(6):825-37.

17. da Silva ALG, da Rosa HT, Bender E, da Rosa PR, Salvador M, Charlier CF, et al. Effect of physical exercise on the level of DNA damage in chronic obstructive pulmonary disease patients. ISRN Pulmonology. 2013;2013: 907520.

18. da Silva AL, da Rosa HT, Karnopp TE, Charlier CF, Ellwanger JH, Moura DJ, et al. Evaluation of DNA damage in COPD patients and its correlation with polymorphisms in repair genes. BMC Med Genet. 2013;14:93.

19. Lim SC, Ju JY, Chi SY, Ban HJ, Kwon YS, Oh IJ, et al. Apoptosis of T lymphocytes isolated from peripheral blood of patients with acute exacerbation of chronic obstructive pulmonary disease. Yonsei Med J. 2011; 52(4):581-7.

20. Mizumura K, Cloonan SM, Nakahira K, Bhashyam AR, Cervo M, Kitada T, et al, Mitophagy-dependent necroptosis contributes to the pathogenesis of COPD. J Clin Invest. 2014;124(9):3987-4003.

21. Vandenabeele P, Galluzzi L, Berghe TV, Kroemer G. Molecular mechanisms of necroptosis: an ordered cellular explosion. Nat Rev Mol Cell Biol. 2010; 11(10):700-14

22. Behar SM, Divangahi M, Remold HG. Evasion of innate immunity by Mycobacterium tuberculosis: is death an exit strategy? Nat Rev Microbiol. 2010;8(9):668-74
23. Behar SM, Martin CJ, Nunes-Alves C, Divangahi M, Remold HG. Lipids, apoptosis, and cross-presentation: links in the chain of host defense against Mycobacterium tuberculosis. Microbes Infect. 2011;13(8-9):749-56.

24. Assis PA, Espíndola MS, Paula-Silva FWG, Rios WM, Pereira PAT, Leão SC, et al. Mycobacterium tuberculosis expressing phospholipase C subverts PGE2 synthesis and induces necrosis in alveolar macrophages. BMC Microbiol. 2014;14:128

25. Bonassi S, Znaor A, Norppa H, Hagmard L. Chromosomal aberrations and risk of cancer in humans: an epidemiologic perspective. Cytogenet Genome Res. 2004;104(1-4):376-82.

26. Cheng TJ, Christiani DC, Xu X, Wain JC, Wiencke JK, Kelsey KT. Increased micronucleus frequency in lymphocytes from smokers with lung cancer. Mutat Res. 1996:349(1):43-50.

27. Hemminki K, Frank C, Försti A, Musak L, Kazimirova A, Barancokova M, et al. Metabolic gene variants associated with chromosomal aberrations in healthy humans. Genes Chromosomes Cancer. 2015;54(4):260-6.

28. Casella M, Miniati M, Monti S, Minichilli F, Bianchi F, Simi S. No evidence of chromosome damage in chronic obstructive pulmonary disease (COPD). Mutagenesis. 2006;21(2):167-71.

29. Sadowska AM, Klebe B, Germonpré P, De Backer WA. Glucocorticosteroids as antioxidants in treatment of asthma and COPD New application for an old medication? Steroids. 2007:72:1-6.

30. Antoniu SA. Effects of inhaled therapy on biomarkers of systemic inflammation in stable chronic obstructive pulmonary disease. Biomarkers. 2010;15(2):97-103

31. Stolarek R, Bialasiewicz P, Krol M, Nowak D. Breath analysis of hydrogen peroxide as a diagnostic tool. Clin Chim Acta. 2010;411(23-24):1849-61.

32. Bonassi S, Neri M, Lando C, Ceppi M, Lin YP, Chang WP, et al. Effect of smoking habit on the frequency of micronuclei in human lymphocytes: results from the Human MicroNucleus project. Mutat Res. 2003:543(2):155-66.

\section{Submit your next manuscript to BioMed Central and we will help you at every step:}

- We accept pre-submission inquiries

- Our selector tool helps you to find the most relevant journal

- We provide round the clock customer support

- Convenient online submission

- Thorough peer review

- Inclusion in PubMed and all major indexing services

- Maximum visibility for your research

Submit your manuscript at www biomedcentral.com/submit

C Biomed Central 